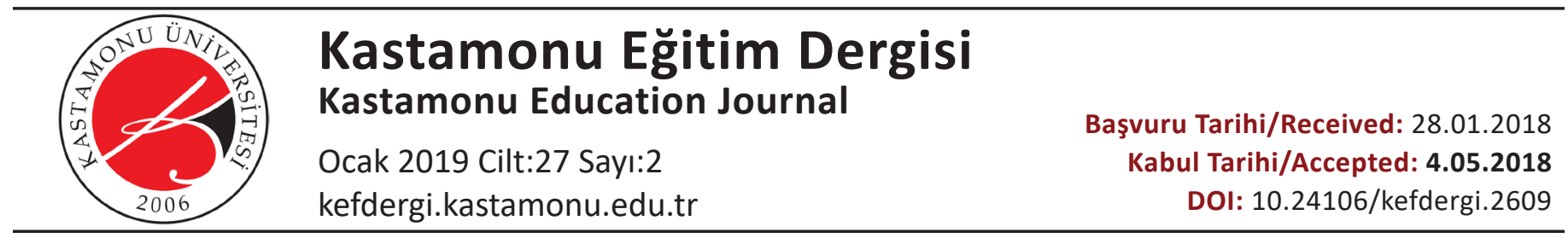

\title{
Sosyal Bilgiler Ders Kitaplarında Güncel Konulara Yer Verilme Durumunun İncelenmesi
}

\section{Evaluation of Usage Level of Current Issues in The Textbooks of Social Studies}

\author{
Ayşe TAŞKIN ${ }^{1}$, Hatice MEMişOĞLU²
}

\section{Özet}

Bu araştırmanın amacı, Sosyal Bilgiler ders kitaplarında güncel konulara yer verilme durumunu tespit etmektir. Bu amaçla toplam 9 adet (5. - 6. ve 7. sınıf) Sosyal bilgiler ders kitabı incelenmiştir. Araştırmada nitel araştırma yöntemlerinden doküman inceleme kullanılmıştır. Doküman olarak ders kitaplarından yararlanılmıştır. Ders kitaplarında güncel konulara yer verilme düzeyi tespit edildikten sonra, elde edilen bu veriler ışığında değerlendirmeler yapılmıştır. Bulgular sonucunda, güncel konuların ünitelerde eşit şekilde dağılımının olmadığı tespit edilmiştir. Bu durum, öğrencilerin güncel olaylara karşı duyarlı olmalarını sağlamak amacıyla sosyal bilgiler ders kitaplarında daha fazla güncel olaya yer veren düzenlemelerin gerekliliği ortaya çıkarmaktadır.

Anahtar Kelimeler: Sosyal bilgiler, ders kitabı, güncel konular

\section{Abstract}

The object of this research is to determine the inclusion of current issues in textbooks of social studies. For this purpose, a total of 9 (5th - 6th and 7th grade) social studies textbooks were examined. In the research, document review method was used among the qualitative research methods. Textbooks were used as document. After the level of giving the current topics in the textbooks was determined, evaluations were made on these obtained data. As a result, it has been found that the current topics are not evenly distributed in the units.This leads to the need for regulations that provide more up-to-date information in social studies textbooks to ensure that students are sensitive to current events.

Keywords: Social sciences, textbook, current issues.

1. Bolu Abant İzzet Baysal Üniversitesi, Eğitim Bilimleri Enstitüsü, Bolu, Türkiye; https://orcid.org/0000-0002-6910-871X

2. Bolu Abant İzzet Baysal Üniversitesi, Eğitim Fakültesi, Bolu, Türkiye; https://orcid.org/0000-0003-3987-8454

Atıf / Citation: Taşkın A., \& Memişoğlu, H. (2019). Sosyal bilgiler ders kitaplarında güncel konulara yer verilme durumunun incelenmesi.Kastamonu Education Journal, 27(2), 599-610. doi:10.24106/kefdergi.2609 


\section{Extended Summary}

\section{Purpose}

The purpose of this research is to determine the level of current issues in Social Studies textbooks. For this purpose, 35 th grade, 3 6th grade, and 3 7th grade social studies textbooks which are decided to be taught during 2014-2015, 2015-2016 and 2016-2017 academic years are examined. The following questions are tried to be answered by this research:

1- What is the frequency of inclusion of current issues on the basis of class and book in Social Studies textbooks?

2- How is the use of current issues in 5th grade primary school textbooks?

3- How is the use of current issues in 6th grade primary school textbooks?

4- How is the use of current issues in 7th grade primary school textbooks?

Method

In this research, document review which is one of the qualitative research methodsis used. As it is known, in the document review method, different written and visual materials such as available archive records, books, magazines, biographies, diaries, letters, movies, radio, and television programs related to the subject are examined.In this study, the document review method is used because it is possible to examine the textbooks that are evaluated within the scope of the written material and its appropriateness for the research.

Findings

Within the scope of findings, 4 tables containing information about books are designed, examined and interpreted in the findings part. According to these tables, it is found that the frequency of inclusion of current issues in 5th grade textbooks are higher during 2014-2015 academic year.In the case of 6th grade textbooks, it is seen that they include the most amount of current issues than whole textbooks during 2015-2016 academic year. While examining 7th grade textbooks used during 2016-2017 academic year, it is examined that it contains more current issues than other textbooks. It is thought that the change in the situation about placing current issues is related to the writers of the books, while Social Studies program have not been changed yet. Internet news are the resource that contains the highest amount of current issues in 5.1. book (27 pieces), second one is reports (11 pieces), then banners (7 pieces) and the least one is magazine news (2 pieces). In the 5.2. book, mostly reports (23 pieces), then TUiK data (3 pieces), then internet news ( 2 pieces), and banners which are the least one (1 piece) are used. In the 5.3. book, mostly internet news ( 28 pieces), then reports ( 5 pieces), banners ( 3 pieces) and TUiK data which is the least one are used. This shows that while current issues are mentioned in the textbooks, reports and internet sources are used mostly. In 3 chapters in 5.1 . and 5.3. books, there are no current issues, it is found that there are current issues in all chapters of 5.2. book.

When books are examined in general, it is determined that all books contain current issues and 6.2 book contains twice as many current issues as the amount in the other books.

\section{Conclusion and Discussion}

It is of utmost importance that subjects in the textbooks are related to current events. Due to the current events that are experienced and likely to happen, the interest in the subject also increases.When we look at the textbooks that we have examined in this respect, it is confirmed that current issues are placed in all chapters except for 1 chapter out of 8 chapters in 5.1.book out of 9 textbooks, current issue distributions according to chapters are not equal, and internet news are mostly used while mentioning these subjects.

Current issues in all chapters of 5.2. bookareplaced. However, there is no equal distribution of current issues in terms of chapters in this book. For example, there are 1 current issue in 1st, 4th, and 5th chapters, while 9 current issues are placed in 3 rdchapter. It is though that the subjects in the chapter are not related to current issues. 29 current issues are placed in total and mostly used resource is reports.

While totally 37 current issues are placed in 5.3. book, it is found that there are no current issues in 2 ndand 5 th chapters and mostly used resource is internet news. The book which includes most current news out of 3 books is the one taught during 2014-2015 academic year.

While in 1st And 6th chapters in 6.1. book, there are no current issues, it is found there are 20 current issues included. This is the book that contains least amount of current issues among 9 books examined. As this book includes current issues, the mostly used resource is internet news.

In all chapters of 6.2. book, there are current issues. This book is the one that includes highest amount of current issues among all books that are examined. However, there is no equal distribution in terms of chapters in this book, as in all other books. The mostly used resource is reports in the book.

As in 6.2. book, there are current issues in all chapters of 6.3. book and 30 current issues are found. The mostly used resource is reports.

In all chapters of 7.1, 7.2. and 7.3. books, current issues are situated,and sources mostly used are internet news in each 3 books. 35 current issues in 7.1. book, 26 in 7.2 book are placed while 54 current issues are given in 7.3. book.

When books are examined in general, it is not possible to say that there is a direct increase or decrease in the number of current events in the textbooks, neither as a class nor as an educational year. However, even though some chapters do not have current issues, it can be said that the inclusion of current topics in all chapters except 1 or 2 chapters is interesting for the students and it is positive in terms of realizing the objectives of the course. 


\section{Giriş}

İnsan sosyal bir varlık olduğu için, yaşadığı çevreye uyum sağlarken çevresinde neler olup bittiğinin de farkında olabilmesi önemlidir. İçinde yaşadığı çevre, ülke ve dünyada yaşanan her türlü olay, değişmeler ve gelişmeler doğrudan ya da dolaylı olarak bireyi etkiler. Bu nedenle, güncel konuların öğretimi önemlidir. Bu bağlamda, bu görevin yerine getirilmesinde okullar, okullar vasıtasıyla Sosyal Bilgiler dersleri ve ders kitapları büyük önem taşımaktadırlar. Güncel olayların derslerde, özellikle de Sosyal Bilgiler derslerinde kullanılması, öğrencinin okulda öğrendiği bilgi ile gerçek hayat arasında bağlant kurmasını, edindiği bilgiyi gerçek hayatta uygulamasını, yaşadığı yerdeki ve ülkedeki güncel olayları daha bilinçli takip etmesini sağlar (Erden, tarihsiz). Bu nedenle bu kadar önem arz eden güncel konuların öğretimine dikkat edilmesi gerekir.

Uzak veya yakın çevremizde yaşanan olaylarla ilgili kimimizin az, kimimizin ise daha çok bilgisi vardır. Yazılı ve görsel medya meydana gelen olayları ele aldığında o olay en çok konuşulan olay hale gelir. Tabii bu olayın etki süresi o olaydan etkilenme durumuna ve kişisine göre değişebilir. Bireyin yakın çevresinde, yaşadığı ülkede ve dünyada meydana gelen, birey, toplum ve insanlık için önemli etkileri olan yeni olaylara "güncel olaylar" denir. Gazete, dergi, televizyon, internet ve radyo gibi kitle iletişim araçları ile insanlara duyurulan haberler güncel olaylardır. Bir olayın güncel olay olması için etkisini sürdürüyor olması ya da yeni meydana gelmiş olması gerekmektedir (Gedik, 2008). Güncel olaylar, eğitim ve öğretim için okulda son derece önemli bir ortam oluşmasına olanak tanır. Özellikle verilecek örnekler öğretimin yapıldığı yere ne kadar yakın olursa güncel olayın değeri de o kadar artar (Binbaşığlu, 2004). Derste kullanmak için programla ve toplum yaşantısıyla ilgili olan güncel olaylar seçilmelidir. Güncel olaylarla konular arasında somut bir bağ olmalıdır. Michaelis ve Garcia'ya (1996) göre, derste kullanılabilecek güncel olayları seçerken dikkat edilmesi gereken hususlar şu şekilde sıralanabilir: Güncellik, uygunluk, güvenilirlik, eğitimsel değer, ilgililik (konu ile yaşantılarla ilişkili), yeterli zaman, olanak, yararlılık, süreklilik, yenilik, faaliyet alanı, önem ve saygınlık. Belirtilen özelliklere, güncel konulara yer verilirken öğretmenin önem vermesi gerekmektedir (Nas, 2000).

Yeni yaşanmış bir güncel olay hakkında konuşulması, ardından öğrencilerden olay hakkında çözüm önerileri alınması, öğrencilerin hem olaya dikkatini çekecek hem de ileride yaşanabilecek aynı ya da benzeri bir olay karşısında öğrendiklerini uygulama şansını yakalayabilmelerine olanak sağlayacaktır. Böylece güncel olaylar hakkında farkındalık oluşturulacak ve öğrencinin yaşanabilecek muhtemel olaylar hakkında fikir sahibi olmaları ve daha duyarlı olmalarını da sağlanacaktır. Güncel olayların öğretimde yakın çevreden uzağa yaklaşımı daha etkili olmaktadır. Sosyal Bilgiler dersi, diğer derslere oranla günlük olayları daha fazla ele alan bir derstir. Çünkü konuları toplumsal olaylardan oluşur. Öğrencilerin toplumsal olaylarla ilgilenen, duyarlı bireyler haline getirilmesinde güncel olaylardan yararlanır. Böylece, öğrencilerin toplumu daha yakından tanıyan, gerçekçi bakış açısıyla olaylara bakabilen bireyler olarak yetişmelerine firsat verir. Ayrıca, amacı iyi vatandaş yetiştirmek olan Sosyal Bilgiler dersi güncel olayları iyi analiz ederek kötü olaylardan ders çıkarılmasını sağlayabilir (Şimşek, 2017).

Sosyal bilgiler dersinde güncel kolayların öğretimi, vatandaşlık bilgi ve becerilerini geliştirmeye, anlamlı konulara kaynak oluşturmaya, öğrenme ortamının ilgi çekiciliğini arttrmaya, vatandaş olarak yaşadığı dünyayı daha iyi anlamaya; empati, hoşgörü gibi duyuşsal özelliklerin kazanılmasına, eleştirel düşünme becerisini geliştirmeye, geçmişi ve bugünü anlamaya katkı sağlar (Kaltsounis, 1987). Öğrencilerin güncel olaylara dikkatinin çekilmesi, bunlarla yaşanılan çevrede gerçekleşebilecek güncel bir olay arasında bağlant kurmasına olanak sağlaması açısından ders kitaplarında güncel olaylara yer verilmesi bu yararlarından dolayı önem arz etmektedir. Bu bağlamda, güncel konuların öğretimi kapsamında 5.,6. ve 7. sınıf Sosyal Bilgiler ders kitaplarında güncel konulara yer verilip verilmediğinin tespit edilmesi, varsa eksiklerin belirlenerek yeni hazırlanacak kitaplarda bu konuya önem verilmesine rehberlik etmesi açısından yapılan çalışma önem teşkil etmektedir.

Güncel konularla ilgili olarak sosyal bilgiler öğretmenleri ve öğrencilerinin görüşlerini almaya yönelik nitel ve deneysel çalışmalar bulunmaktadır (Smith, 1963; Kaltsounis, 1987; Michaelis ve Garcia, 1996; Wilson ve diğerleri, 2002; Deveci, 2007; Ünlüer, 2008; Deveci ve Arın, 2008, Bayır, 2010; Akengin ve İbrahimoğlu, 2010; Eryılmaz ve Köse, 2017; Dinç ve Acun, 2017). Bu çalışmalarda, Sosyal Bilgiler dersinin güncel olaylardan yararlanılarak anlatımasının öğrencilerin derse karşı ilgilerinin artması açısından katkı sağladığı, derslerin daha zevkli geçtiği, öğrencilerin akademik başarısının arttğı ve öğrenmelerinin daha kalıcı olduğu, başarıyı arttırdığı, sosyal problemler konusunda farkındalık kazandırdığı sonucuna ulaşılmıştır. Gedik (2010) tarafindan yapılan çalışmada ise, derslerde en çok kullanılan güncel konuların neler olduğu konusunda öğrenci görüşleri alınmış, önemli güncel olaylar ve güncel kişilerin kimler olduğu tespit edilmeye çalışılmıştır. Yapılan bazı çalışmalarda (Gedik, 2008; Akdağ ve diğerleri, 2014; Memişoğlu ve Güçin, 2017) sosyal bilgiler öğretmenleri, güncel konuları sosyal bilgiler dersinin tamamlayıcısı olarak gördüklerini, derste yeri geldikçe kullandıklarını, güncel konuların konuları ilişkilendirmede önemli olduğunu belirtirken; ders kitaplarının güncel konular açısından yetersiz oldu- 
ğunu ifade etmişlerdir. Görüldüğü gibi, güncel konuların öğretiminin öğrenciye birçok katkısı bulunduğu çeşitli araştırma sonuçlarında yer almasına rağmen, öğretmenler ders kitaplarında güncel konuların yetersizliğini belirtmektedirler.

Buna rağmen, ders kitaplarında güncel konulara yer verme durumuna ilişkin çalışmaların (Gedik, 2008) yeterli olmadığı görülmüştür. Bu çalışmada ise, farklı eğitim-öğretim yıllarına ait ders kitapları karşılaştırmalı olarak incelenmiş olup böyle bir çalışmaya rastlanılmamış olması nedeniyle, çalışmanın alan yazına faydalı olacağı düşünülmektedir.

\section{Araştırmanın Amacı}

Bu araştırmanın amacı, Sosyal Bilgiler ders kitaplarında güncel konuların ne düzeyde bulunduğunu tespit etmektir. Bu amaçla 2014-2015, 2015-2016 ve 2016-2017 eğitim öğretim yıllarında okutulmasına karar verilen 3 adet 5. sınıf, 3 adet 6 . sınıf ve 3 adet 7. sınıf Sosyal Bilgiler ders kitabı incelenmiştir. Bu araştırmayla aşağıdaki sorulara cevap aranmıştr:

- Sosyal Bilgiler ders kitaplarında yıllara göre sınıf ve kitap bazında güncel konulara yer verilme sıklı̆ı nedir?

- Ilköğretim 5. sınıf ders kitaplarında güncel konuların kullanım durumu nedir?

- Illköğretim 6. sınıf ders kitaplarında güncel konuların kullanım durumu nedir?

- Illköğretim 7. sınıf ders kitaplarında güncel konuların kullanım durumu nedir?

\section{Yöntem}

\section{Araştırmanın Modeli}

Bu araştırmada nitel araştırma modeli kullanılarak veriler toplanmıştır. Nitel araştırma, gözlem, görüşme, doküman analizi gibi nitel veri toplama yöntemlerinin kullanıldığı, algıların ve olayların doğal ortamda gerçekçi ve bütüncül bir biçimde ortaya konmasına yönelik nitel bir sürecin izlendiği araştırma olarak tanımlanmaktadır (Yıldırım ve Şimşek, 2013).

\section{Araştırmanın Deseni}

Araştırmada nitel araştırma yöntemlerinden biri olan doküman incelemeden yararlanılmıştır. Bilindiği gibi doküman inceleme yönteminde araştrılmak istenen konuyla ilgili mevcut arşiv kayıtları, kitaplar, dergiler, biyografiler, günlükler, mektuplar, filmler, radyo ve televizyon programları gibi birbirinden farklı yazılı ve görsel materyaller incelenir (Balcı, 2007). Bu araştırmada doküman inceleme yöntemi, araştırmanın amacına uygunluğu ve yazılı materyal kapsamında değerlendirilen ders kitaplarını incelemeye olanak sağlaması nedeniyle kullanılmıştır.

\section{Verilerin Toplanması ve Analizi}

Araştırmada doküman analizi aşamaları kullanılmıştır. Dokuman analizi aşamaları; dokümanlara ulaşma, özgünlüğü (orjinalliği) kontrol etme, dokümanları anlama, verileri analiz etme ve verileri kullanmadır (Yıldırım ve Şimşek, 2013). Bu amaçla 2014-2015, 2015-2016 ve 2016-2017 eğitim öğretim yıllarında MEB tarafindan okullarda okutulmasına karar verilen 3 adet 5. sınıf, 3 adet 6 . sınıf ve 3 adet 7. sınıf Sosyal Bilgiler ders kitabı seçilmiştir. Çalışmaya kitapların kodlanması ile başlanmıştir. Buna göre;

- 2014-2015 eğitim öğretim yılında 5. sınıflarda okutulan kitap 5.1.

- 2015-2016 eğitim öğretim yılında 5. sınıflarda okutulan kitap 5.2

- 2016-2017 eğitim öğretim yılında 5. sınıflarda okutulan kitap 5.3.

- 2014-2015 eğitim öğretim yılında 6. sınıflarda okutulan kitap 6.1.

- 2015-2016 eğitim öğretim yılında 6. sınıflarda okutulan kitap 6.2.

- 2016-2017 eğitim öğretim yılında 6. sınıflarda okutulan kitap 6.3

- 2014-2015 eğitim öğretim yılında 7. sınıflarda okutulan kitap 7.1

- 2015-2016 eğitim öğretim yılında 7. sınıflarda okutulan kitap 7.2.

- 2016-2017 eğitim öğretim yılında 7. sınıflarda okutulan kitap 7.3.

olarak kodlanmıştır. Araştırmada ölçütler belirlenmiştir. Ders kitabında bulunan güncel konular için haber kaynağı niteliğinde olan gazete, dergi ve internet sitesinden alınarak ders kitabına konulan haberler, TUiK'e ait araşttrma sonuçları ve tanıtım afişleri ölçüt olarak alınmıştır. Sadece fotoğrafla belirtilmiş olan güncel olaylara ve haber kaynağı belirtilmeyen yazılara araştırma kapsamında yer verilmemiştir. Ayrıca araştırma güncel konularla ilgili incelenen kitaplarda tespit edilen ve güncelliğini koruyan ve güncel olay tanımına uygun olduğu düşünülen verilerle sınırlıdır. Kodlanan her bir kitap üniteler bazında incelenmiş, belirtilen kriterler ışığında incelenerek kitaplarda yer alan güncel konuların hangi konularla ile ilgili olduğu, sayı değerleri ve haber kaynağı sayısallaştırılmıştır. 
Çalışmada elde edilen verilerin çözümlenmesinde betimsel analiz tekniği kullanılmıştır. Betimsel analizde amaç, görüşme ve gözlem sonucu elde edilen verilerin düzenlenerek ve yorumlanarak okuyucuya aktarmaktr. Veriler daha önceden belirlenmiş temalara göre sınıflandırılır, özetlenir ve yorumlanır (Yıldırım ve Şimşek, 2013).Betimsel analiz yöntemi ile belirlenen veriler tablolaştırılarak, yorumlanmıştır. Güncel konuların kaynağı belirtilirken kısaltmalardan yararlanılmıştir. Kısaltmalardan (g.h.) : gazete haberi, (d.h.) : dergi haberi, (af.) : afiş, (TUiK): Türkiye İstatistik Kurumu verileri, (k): kitap anlamında kodlanmıştır. Ayrıca tabloda verilen bilgilere ait ders kitaplarından alıntılar yapılmış, görseller kullanılmış, bunların hangi sayfada yer aldığı da belirtilmiştir.

Geçerlik ve güvenirliği sağlama aşamasında ise; nitel araştırmada güvenilirliği artırmak için araştırmacıların bazı önlemler almaları önerilmektedir. Bu önlemler araştırmada kullanılan stratejilerin neden\nasıl kullanıldığının belirgin hale getirilmesi ve bu sayede diğer araştırmacıların bu stratejileri benzer şekilde kullanabilmesine olanak tanıması ile ilişkilidir (Yıldırım ve Şimşek, 2013). Geçerlik ve güvenirlik, araştırma sonuçlarının inandırıcılığını sağlamak ve artırmak için araştırmalarda en yaygın olarak kullanılan iki ölçüttür. Bu noktada araştırmacı izlediği aşamaları ayrıntlı ve açık bir biçimde rapor ettiği takdirde araştırmanın dış güvenirliliği, araştırma sonuçlarını kendi tercih ve yönelimlerine göre biçimlendirmediğini okuyucuya ikna ettiği taktirde de araştırmanın iç güvenilirliği konusunda adım atmış olur (Kabapınar, 2003). Ayrıca, araşttrma sonucu rapor edilirken bulgular bölümünün orijinalliği bozulmadan, doğrudan alıntılara yer verilmesi de araştırmanın iç güvenilirliğini önemli ölçüde yükseltir (Yıldırım ve Şimşek, 2013). Bu nedenle bu çalışmada da araştırmanın bulguları kısmında tablolarda belirtilen konu ile ilgili doğrudan görsellere, örneklere yer verilmiştir.

Nitel araştırmalarda betimsel analizinin güvenirliği özellikle kodlama işlemine bağııdır. Kategorilerin taşıması gereken en önemli özelliklerden biri aynı dokümanı, aynı amaç doğrultusunda kullanan başka bir araştırmacının da büyük ölçüde benzer sonuçlara ulaşabileceği açıklıkta olmasıdır (Tavşancıl ve Aslan, 2001). Bu nedenle, kategorilerin yorumlanmasının araştırmacıdan araştırmacıya ya da iki farklı zamanda değişmemesi gerekir. Araştırma sırasında iki araştırmacı tarafindan ayrı ayrı ders kitapları incelenerek, ders kitaplarında yer alan güncel konular gazete haberi, dergi haberi, afiş, TÜiK verileri ve kitaplardan alınt yapılmış bölümler olarak işaretlenmiş, çalışma sonucunda iki araştırmacının belirlediği güncel konular karşılaştırılmıştı. Bütün karşılaştırmalarda görüş birliği ve görüş ayrılığı sayıları tespit edilerek, araştrrmanın güvenilirliği Miles ve Huberman'ın (1994: 64) formülü (Güvenirlik = Görüş Birliği / Görüş Birliği + Görüş Ayrılığı) kullanılarak hesaplanmış ve sonuç \%90 bulunmuştur.

\section{Bulgular ve Yorumlar}

\section{Tablo 1. Sosyal Bilgiler Ders Kitaplarında Yıllara Göre Sınıf ve Kitap Bazında Güncel Konulara Yer Verilme Sıklığı}

\begin{tabular}{lcc}
\hline Sınıf & Eğitim-Öğretim Yılı & Güncel Konu Sayısı \\
\hline 5. sınıf & $2014-2015(5.1)$. & 47 adet \\
5. sınıf & $2015-2016(5.2)$. & 29 adet \\
5. sınıf & $2016-2017(5.3)$. & 37 adet \\
6. sınıf & $2014-2015(6.1)$. & 20 adet \\
6. sınıf & $2015-2016(6.2)$. & 76 adet \\
6. sınıf & $2016-2017(6.3)$. & 30 adet \\
7. sınıf & $2014-2015(7.1)$. & 35 adet \\
7. sınıf & $2015-2016(7.2)$. & 26 adet \\
7. sınıf & $2016-2017(7.3)$. & 54 adet \\
\hline
\end{tabular}

Tablo 1'e göre 5. sınıf ders kitaplarında güncel konulara yer verilme sıklığının 2014-2015 eğitim öğretim yılında daha fazla olduğu görülmektedir. 6. sınıf ders kitaplarında ise 2015-2016 eğitim öğretim yılındaki kitapta diğer tüm kitaplardan daha fazla güncel konuya yer verildiği görülmektedir. 7. sınıf ders kitapları incelendiğinde ise diğerlerinden farklı olarak 2016-2017 eğitim öğretim yılında okutulan ders kitabında daha fazla güncel konuya yer verildiği görülmektedir. Sosyal Bilgiler programı daha değişmemişken kitaplardaki güncel konulara yer verilme durumundaki bu değişikliğin kitapların yazarlarıyla ilişkili olduğu düşünülmektedir. Kitaplar genel olarak incelendiğinde, tüm kitaplarda güncel konulara yer verildiği ancak, 6.2. kitapta ise diğer kitaplarda yer alan miktarın 2 katı kadar daha fazla güncel konuya yer verildiği tespit edilmiştir. 
Tablo 2. 5. Sınıf Sosyal Bilgiler Ders Kitaplarında Ünite Bazında Günlük Konulara Yer Verilme Durumu

\begin{tabular}{|c|c|c|c|}
\hline & 5.1. Kitap & 5.2. Kitap & 5.3. Kitap \\
\hline & Konular (f) Haber kaynağı & Konular(f)Haber Kaynağı & Konular (f) Haber Kaynağı \\
\hline 1. Ünite & Haklar (2) (i.H.) (1) (G.H.) & Haklar (1) (G.H) & Haklar (2) (i.H.) (1)(G.H.) \\
\hline 2.Ünite & YOK & $\begin{array}{l}\text { Tarihi mekân (1) (G.H.) } \\
\text { Kültürel Özellik (1) (G.H.) }\end{array}$ & YOK \\
\hline 3.Ünite & $\begin{array}{l}\text { İklim (2) (i.H.) } \\
\text { Doğal Afet (3) (G.H.) }\end{array}$ & $\begin{array}{l}\text { İklim (1) (G.H.) (1) (i.H.) } \\
\text { Nüfus (1) (TUiK) } \\
\text { Küresel Isınma (1) (G.H.) } \\
\text { Doğal Afet (4) (G.H.)(1) (i.H.) }\end{array}$ & $\begin{array}{l}\text { Nüfus (1) (TUiK) } \\
\text { Doğal Afet (1) (G.H. ) (1) (i.H.) }\end{array}$ \\
\hline 4.Ünite & $\begin{array}{l}\text { Ekonomi (1) (i.H.) } \\
\text { Girişimci (1) (i.H.) } \\
\text { İhracat (1) (i.H.) }\end{array}$ & Ekonomi (1) (G.H.) & $\begin{array}{l}\text { Meslekler (1) (G.í.) } \\
\text { Ekonomi (1) (ì.H.) }\end{array}$ \\
\hline 5.Ünite & $\begin{array}{l}\text { Süreli yayınlar (2) (i..H.) } \\
\text { Bilgi Kaynağı(1) (i.H.) }\end{array}$ & Teknolojik ürünler(1) (G.H.) & YOK \\
\hline 6.Ünite & $\begin{array}{l}\text { Kurumlar (2) (i.H.) } \\
\text { STK (6) (i.H.) (1) (G.H.) } \\
\text { (3) (Af.) (2) (D.H.) }\end{array}$ & $\begin{array}{l}\text { Kurumlar (2) (G.H.) } \\
\text { Kuruluşlar (3) (G.H.) (1) (Af.) }\end{array}$ & Kuruluşlar (11) (I.H.) \\
\hline 7.Ünite & $\begin{array}{l}\text { Dumansız Hava (1) (Af) } \\
\text { Trafik (3) (Af.) } \\
\text { Yönetim (8) (i.H.) (1) (G.H.) }\end{array}$ & $\begin{array}{l}\text { Toplumsal Yaşam (1) (G.H.) } \\
\text { Yönetim (3) (G.H.) }\end{array}$ & $\begin{array}{l}\text { Birlikte Yaşam (1) (Af.) } \\
\text { Yönetim (8) (i.H.) }\end{array}$ \\
\hline 8.Ünite & $\begin{array}{l}\text { İhracat (1) (I.H.) (1) (G.H.) } \\
\text { Ortak Miras (4) (G.H.) }\end{array}$ & $\begin{array}{l}\text { Ekonomi(2) (G.H.) (2) (TUIK) } \\
\text { Turizm(1) (G.H) }\end{array}$ & $\begin{array}{l}\text { Ticaret (2) (i.H.) (1) (G.H.) } \\
\text { Turizm(3) (i.H.) (2) (Af.)1(G.H.) }\end{array}$ \\
\hline
\end{tabular}

Not:Tablo 2, 3 ve 4'de yer alan kısaltmalardan g.h.: gazete haberi, d.h.: dergi haberi, af.: afiş, TUik: Türkiye İstatistik Kurumu verileri, k: kitap anlamında kullanılmıştır.

Tablo 2'ye göre, 5.1. kitapta en fazla güncel konunun yer aldığı kaynak internet haberidir (27 adet), ikinci sırada gazete haberi (11 adet), sonrasında afiş ( 7 adet) ve en az dergi haberidir ( 2 adet). 5.2. kitapta ise en fazla gazete haberi (23 adet), sonra TUik verileri(3 adet), sonra internet haberi ( 2 adet) ve en az afiş ( 1 adet) kullanılmıştr. 5.3. kitapta ise en fazla internet haberi (28 adet), sonra gazete haberi ( 5 adet), afiş ( 3 adet) ve en az TUik verileri ( 1 adet) kullanılmıştır. Bu da gösteriyor ki, ders kitaplarında güncel konulara yer verilirken, en fazla gazete ve internet kaynaklarından yararlanılmıştr. 5.1 ve 5.3. kitaplarda toplamda 3 ünitede güncel konulara yer verilmezken; 5.2. kitapta tüm ünitelerde güncel konulara yer verildiği tespit edilmiştir. 5. sınıf ders kitaplarında yer alan güncel olay örneklerinden bazıları şu şekildedir: 
5.1. nolu kitapta 1. ünitede çocuk hakları ile ilgili bilgi verildikten sonra "14.09.2012" tarihli bir internet haberine yer verilmiştir(s.24).Buna göre;

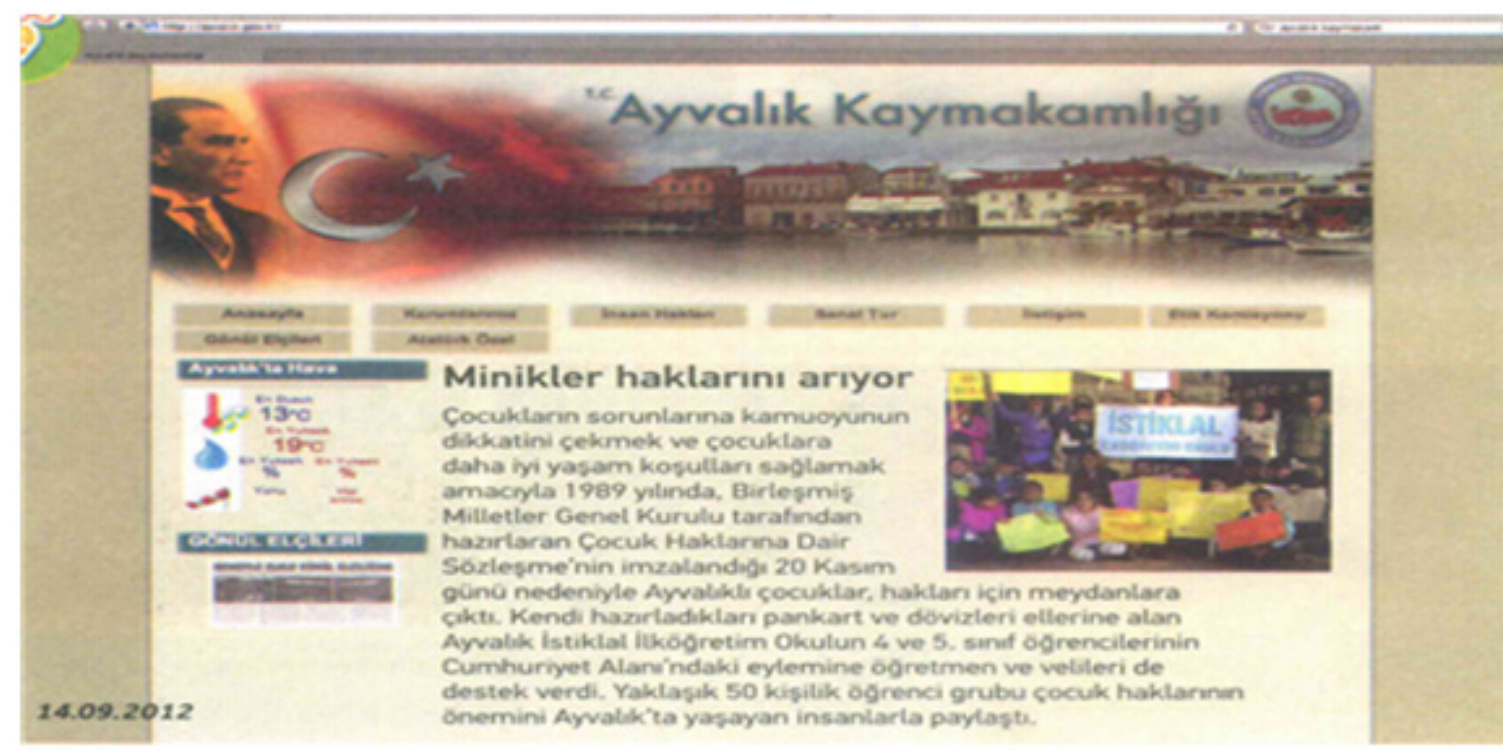

Bu haberi gören çocuk, haklarının neler olduğunu ve neler yapabileceğini öğrenecek, belki kendisi de bu haberdeki gibi bir çalışmayı yapmak isteyecektir. Bu açıdan ders kitaplarında güncel olaylara sadece yazı ile değil görsel olarak da yer verilmesi ve bunun özellikle de tarih verilerek, nerede yapıldığının açıklanmasının olayın öğrenci açısından etkililiğini artrabileceği söylenebilir.

5.3. nolu kitapta 8. ünitede uluslararası ticaret hakkında bilgi verildikten sonra bununla ilgili bir gazete haberine yer verilmiştir (s.165). Buna göre;

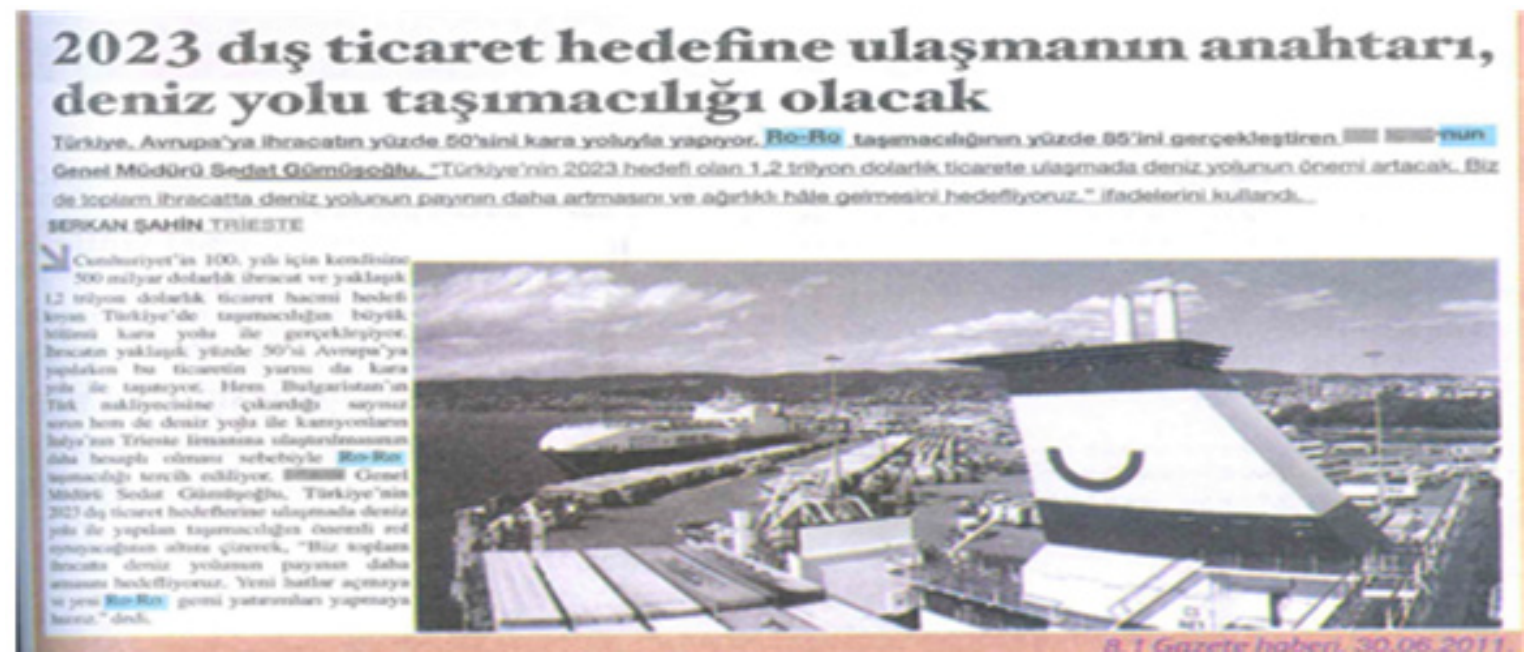

30.06.2011 tarihli bu gazete haberi Ro-Ro taşımacılığını belki de daha önce duymayan bir öğrencinin bu haber sayesinde hem bu taşımacılığa hem de deniz taşımacılığına gereken önemin verilip verilmediği ile ilgili araştırma yapmasını sağlayabileceği gibi, ulaşımın ticaretteki önemine daha çok dikkat etmesini destekleyebilir. 
Tablo 3. 6. Sınıf Sosyal Bilgiler Ders Kitaplarında Ünite Bazında Günlük Konulara Yer Verilme Durumu

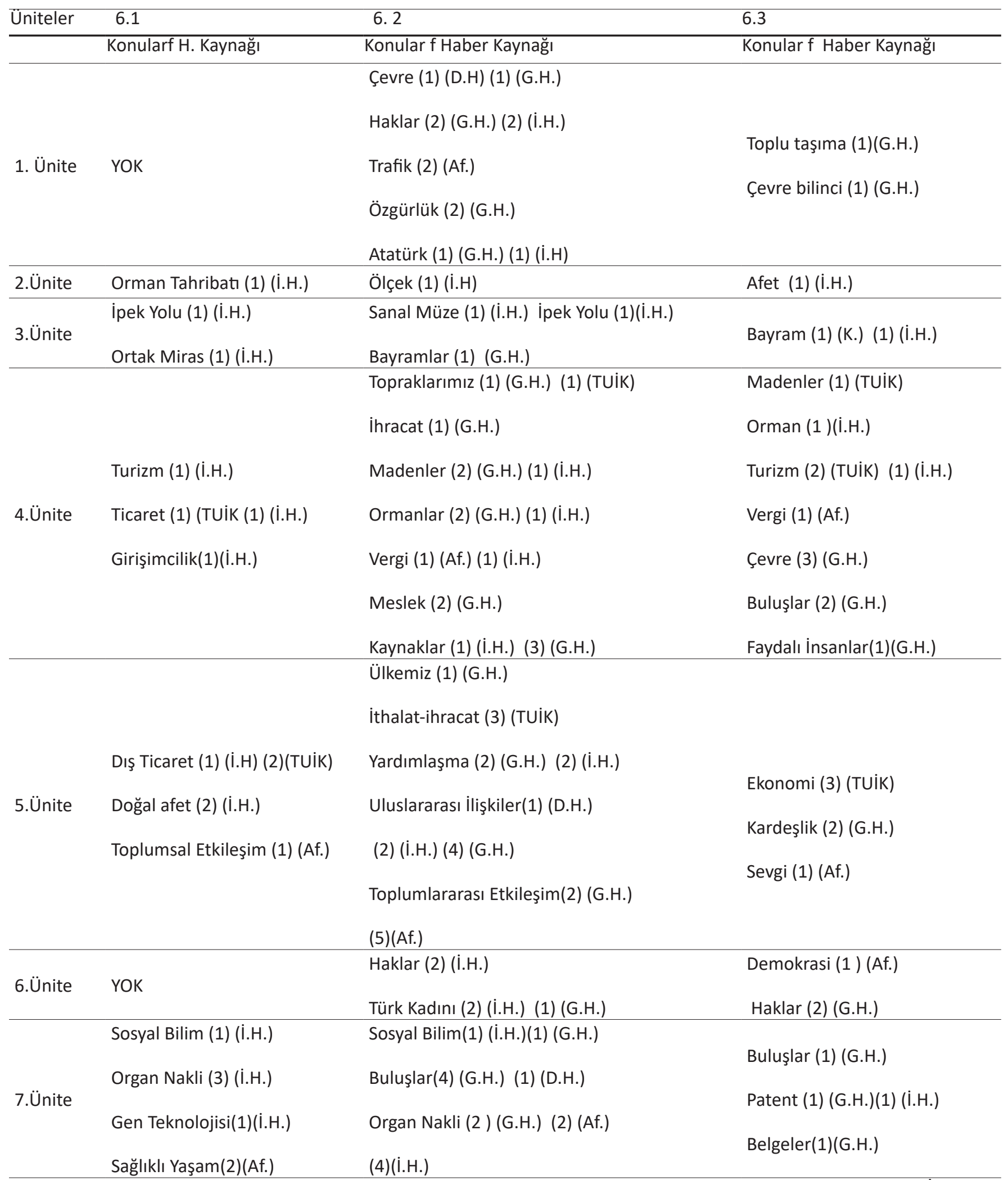

Tablo 3'e göre 6.1. kitapta güncel konuların en fazla yer aldığı kaynak internet haberi(14 adet), sonra TUik verileri (3 adet) ve afişlerdir ( 3 adet). 6.2. kitapta ise en fazla gazete haberi ( 36 adet), sonra internet haberi (23 adet), afiş (10 adet), TUiK verileri (4 adet) ve en az ise dergi haberlerinden(3 adet) yararlanılmıştr. 6.3.kitapta da en fazla gazete haberi (15 adet), sonra TUiK verileri ( 6 adet), sonrasında internet haberleri ( 5 adet), afişler ( 3 adet) ve en az ise kitaptan ( 1 adet) yararlanılmıştr. Tablo 3'e göre ders kitaplarında güncel konulara yer verilirken, 6.1. kitap haricinde tüm kitaplarda en fazla yararlanılan kaynak gazete haberleridir. 6.1.kitapta 1. ve 6. ünite dışındaki tüm ünitelerde güncel konulara yer verilmiştir.

6.3. nolu kitapta 6. ünitede demokrasi konusu anlatıldıktan sonra demokrasi eğitimi kapsamında okullarda yapılan 
"Okul Meclisleri" çalışması ile ilgili afişe (s.135) yer verilmiştir. Öğrencinin eğitim gördüğü okulda eğer bu sistem uygulanmıyorsa bu afiş sayesinde öğrenci bunun nedenini sorgulayabilir. Okul meclisleri çalışması yapılıyorsa da öğrencinin bu uygulamanın daha iyi nasıl yapılabileceği konusunda fikir yürütmesini destekleyici bir unsur teşkil ettiği düşünülmektedir.

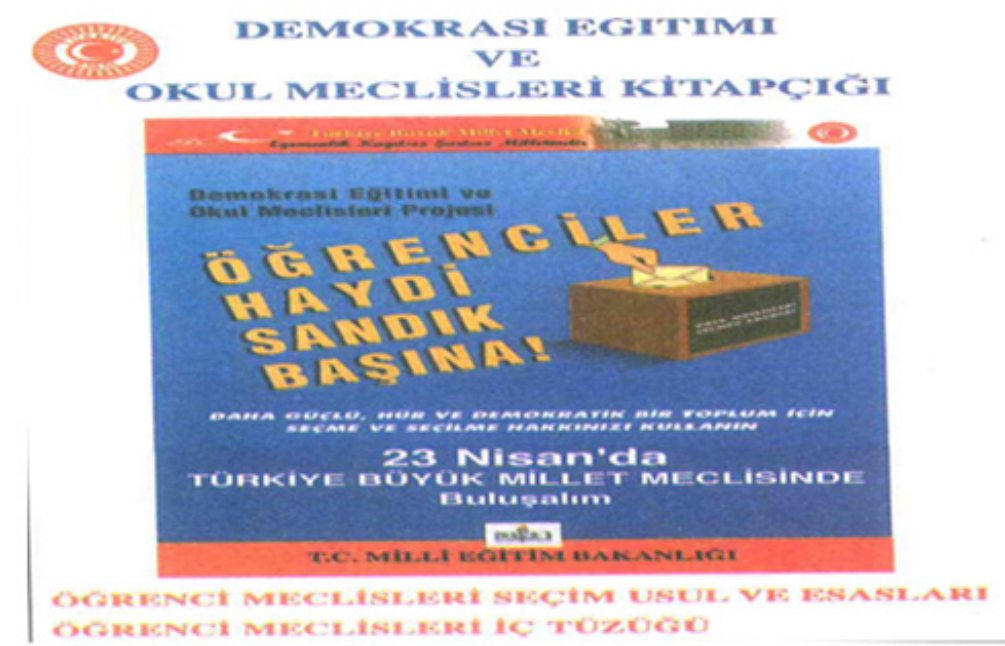

Tablo 4. 7. Sınıf Sosyal Bilgiler Ders Kitaplarında Ünite Bazında Günlük Konulara Yer Verilme Durumu

\begin{tabular}{|c|c|c|c|}
\hline Üniteler & $\begin{array}{l}7.1 \\
\text { Konular fH. Kaynağı }\end{array}$ & $\begin{array}{l}\text { 7. } 2 \\
\text { Konular fH. Kaynağı }\end{array}$ & $\begin{array}{l}7.3 \\
\text { Konular f H. Kaynağı }\end{array}$ \\
\hline 1.Ünite & Haklar (1 )(i.H.) (1) (ilan) & YOK & $\begin{array}{l}\text { Kitle İletişim (4) (i.H.) } \\
\text { Özel Hayat Gizliliği (1) (i.H.) } \\
\text { Resmi Gazete (1) (i.H.) }\end{array}$ \\
\hline 2.Ünite & $\begin{array}{l}\text { Nüfus (6) (TUiK) } \\
\text { Göç (2) (TUiK) (2) (i..H.) }\end{array}$ & $\begin{array}{l}\text { Nüfus (8) (TUiK) } \\
\text { Eğitim(1) (G.H.) } \\
\text { Özgürlük (1) (i.H.) }\end{array}$ & $\begin{array}{l}\text { Nüfus(2) (i.H.)(1) (TUIK) } \\
\text { Eğitim (3) (i.H.) } \\
\text { Göç (1) (i.H.) } \\
\text { Özgürlük(2) (i.H.) }\end{array}$ \\
\hline 3.Ünite & Şehirler (1) (G.H. & Ziraat Bankası (1) (i..H.) & $\begin{array}{l}\text { Osmanlı'da Beylikler (1) (i.H.) } \\
\text { Osmanlı'da Hoşgörü (1) (ì.H.) } \\
\text { Matbaa (1) (i.H.) }\end{array}$ \\
\hline 4.Ünite & Bilim (1) (G.H.) & Bilginler (1) (i..H.) & $\begin{array}{l}\text { Bilimsel Gelişme (2) (ì.H.) } \\
\text { Avrupa'da Bilim (1) (i.H.) }\end{array}$ \\
\hline 5.Ünite & $\begin{array}{l}\text { Yalnız Değilsin (1) (i.H.) } \\
\text { (G.H.) } \\
\text { Ahilik (1)(G.H.) } \\
\text { Meslek (1) (G.H) }\end{array}$ & $\begin{array}{l}\text { Vakıflar (1) (i.H.) } \\
\text { Meslek (1) (i.H.) }\end{array}$ & Meslek (1) (i.H.) (1) (G.H.) \\
\hline 6.Ünite & $\begin{array}{l}\text { Anayasa (4) (Af.) } \\
\text { Yönetim (1) (G.H.) } \\
\text { Birlik (3) (G.H.) }\end{array}$ & $\begin{array}{l}\text { Sosyal Devlet (1) (i.H.) } \\
\text { STK (2) (i.H.) } \\
\text { Çevre (2) (i.H.) }\end{array}$ & $\begin{array}{l}\text { Sosyal Devlet (2) (G.H.) } \\
\text { (2) (i.H.) } \\
\text { Yönetim (2) (i.H.) (3) (G.H.) } \\
\text { Okulda Demokrasi (1) (i.H.) }\end{array}$ \\
\hline
\end{tabular}




\begin{tabular}{llll}
\hline Üniteler & $\begin{array}{l}7.1 \\
\text { Konular fH. Kaynağı }\end{array}$ & $\begin{array}{l}7.2 \\
\text { Konular fH. Kaynağı }\end{array}$ & $\begin{array}{c}7.3 \\
\text { Konularf H. Kaynağı }\end{array}$ \\
\hline Kuruluşlar (4) (i.H.) & Küresel Sorunlar (4) (i.H.) & Küresel Sorun (6) (i.H.) \\
7.Ünite & (1) (G.H.) & (1) (G.H.) (1) (Af.) & Ortak Miras (4) (i.H.) (1) (Af.) \\
& Ülkemiz (1) (G.H.) & Ortak Miras (1) (i.H.) & \\
\hline
\end{tabular}

Tablo 4'e göre 7.1.kitapta en fazla güncel konunun yer aldığı kaynak internet haberi ve gazete haberi(11'er adet), sonra TUiK verileri( 8 adet), afiş(4 adet) ve en az ilandır. 7.2.kitapta ise en fazla internet haberi(15 adet), sonra TUiK verileri( 8 adet), gazete haberi ( 2 adet) ve en az afişten( 1 adet) yararlanılmıştır. 7.3. kitapta ise en fazla internet haberi(36 adet), sonra TUiK verileri(11adet),gazete haberi(6 adet) ve en az ise afişlerden (1 adet) yararlanılmıştr. 7.2.kitabın 1. ünitesi haricinde tüm kitaplarda farklı sayılarda da olsa güncel konulara yer verilmiştir. Genel olarak bakıldığında 7. sınıf ders kitaplarında en fazla yararlanılan kaynak internet haberleri olmuştur.

7.2. nolu kitapta 5. ünitede "Mesleğimi Nasıl Seçmeliyim?” başlığı altında bir internet haberine (s.138) yer verilerek öğrencinin ilerde seçeceği mesleği belirlerken neleri dikkate alması gerektiği haber yoluyla öğrenciye kavratılmaya çalışımıştır:

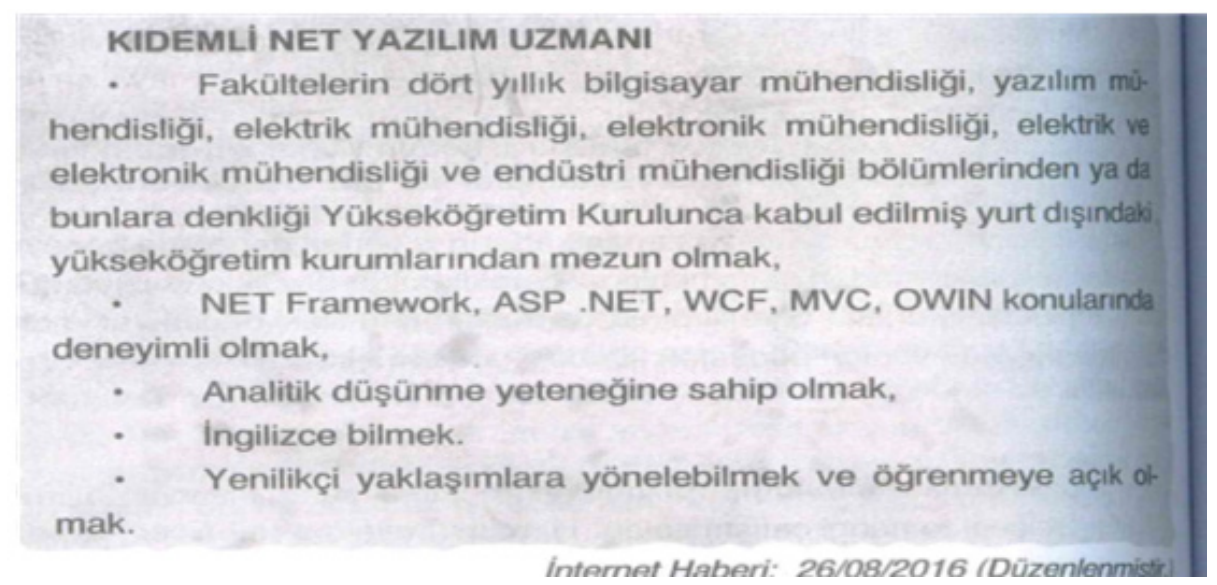

7.3. nolu kitapta da 7. ünitede "Dünya Alarm Veriyor!" başlığı verildikten sonra bununla ilgili internet haberine yer verilmiş (s.174), böylece öğrencinin dünyada yaşanan kıtlığa dikkati çekilmeye çalışılmıştır. Bu yolla öğrencinin konu ile ilgili neler yapabileceğini düşünmesi istenmiştir. Buna göre;

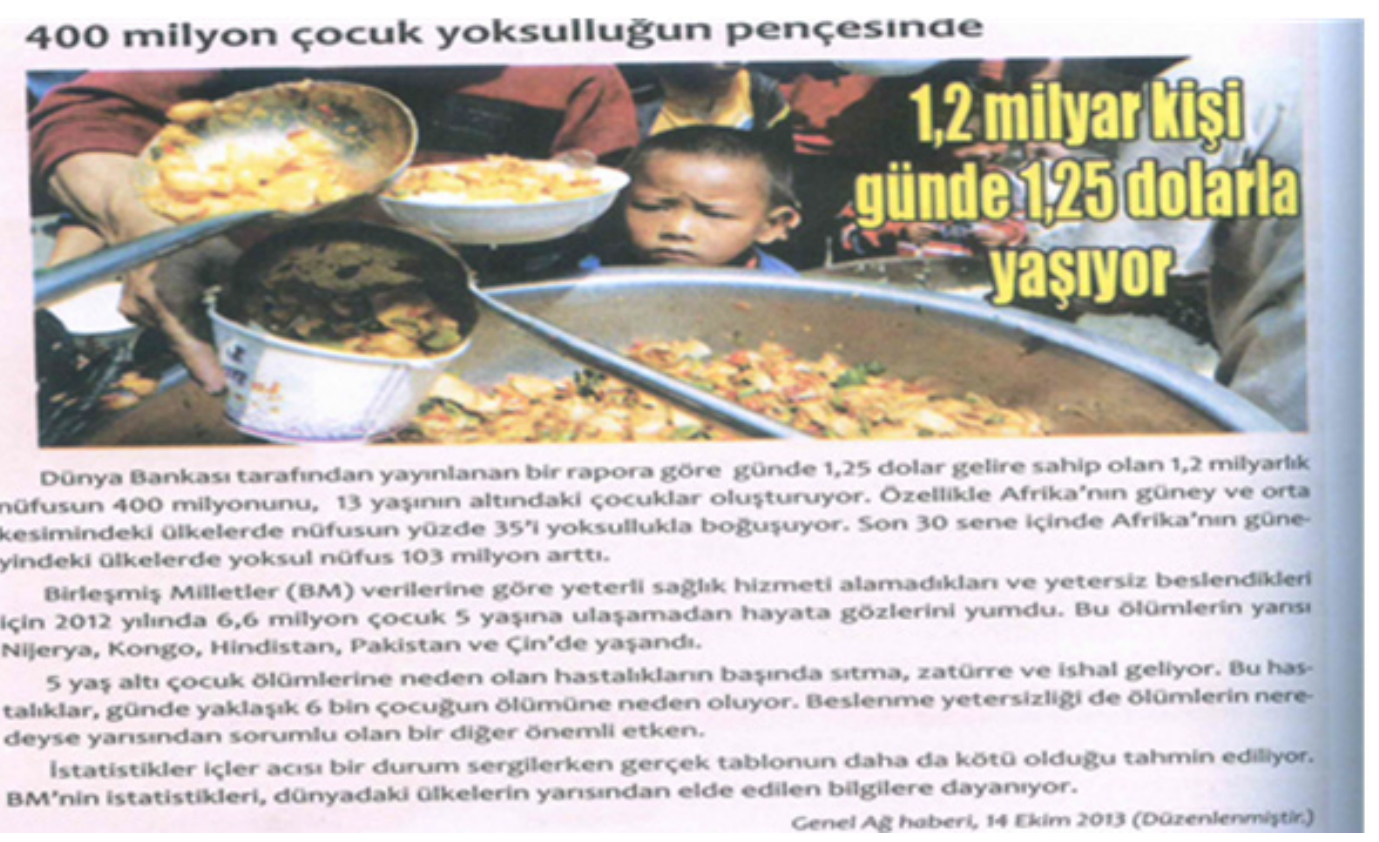


Örnek verilen haber 2013 yılına ait bir haber olmasına rağmen günümüzde de hala etkisini yitirmemesi sebebiyle güncel bir olaydır. Bu haber sonrasında öğrenciye yöneltilen sorular öğrenciyi bu sorunun çözümü için nelere yapılabileceği konusunda düşündürmeye teşvik etmesi açısından önem teşkil etmektedir. Bu haber öğrencinin nasıl bu kadar çocuğun açıık sınırında yaşadığını ve onlar için neler yapabileceğini düşünmesini sağlayabilir. Ayrıca bu tarz bir haber öğrencinin bundan sonra yediği ve belki bitiremediği için çöpe attğı yemekleri bulamayan birçok çocuk olduğunu aklına getirerek israftan uzaklaşmasına da katkı sağlayabilir.

\section{Tartışma}

Güncel olaylar, bireylerin yaşadıkları çevreden haberdar olmalarını, yaşanılan yeni gelişmeleri takip ederek doğru kararlar verebilmeleri aşamasında önemli bir yol gösterici unsur olarak karşımıza çıkmaktadır. Günlük olaylar öğretimi sayesinde daha duyarlı ve empati sahibi bireyler yetiştirmek mümkün olabilir. Günlük hayatta internet, televizyon yoluyla öğrenilmemiş güncel olaylardan ders kitabı yoluyla haberdar olunabilir. Düşünme ile başlayan süreçte eyleme geçilerek, dünyanın değişmesine katkı sağlanabilir. Böylece, Sosyal Bilgiler dersi amacını yerine getirerek ve yaşadığı topluma, ülkesine yararlı vatandaşlar yetiştirmeye katkı sağlayabilir. Bu bağlamda, ders kitaplarında yer alan konuların güncel olaylarla ilişkilendirilmesi çok büyük bir önem arz etmektedir. Yaşanılan ve yaşanma olasılığı yüksek olan güncel olaylar sayesinde de öğrenilecek olan konuya ilgi daha da artabilir.

Bulgularda yer verilen, ders kitaplarında yer alan örnekler incelendiğinde internet ve gazete haberlerinin, TÜik verilerinin ve afişlerinin yer aldığı tüm örneklerin ele alınan konunun günlük hayatla ilişkilendirilmesini ve öğrencinin öğrendikleri ile yaşananlar arasında bağlantı kurmasına olanak sağlaması açısından faydalı olduğu söylenebilir.

Sosyal bilgiler ders kitapları genel olarak incelendiğinde, sınıf ve öğretim yılı bazında güncel olayların sayısında yıllara göre düzenli olarak artı̧ veya azalış meydana gelmediği görülmektedir. Bazı öğretim yıllarında ve sınıflarda güncel olaylara yer verme sayısı artarken bazı öğretim yıllarında düşüş belirlenmektedir. Ancak bazı ünitelerde güncel konulara yer verilmese de (1 veya 2 ünite), tüm ünitelerde güncel konulara yer verilmesinin öğrenciler açısından ilgi çekici ve dersin amaçlarının gerçekleştirilmesine de yardımcı olması açısından sevindirici olduğu söylenebilir. Araştırmada öğretim yıllarına göre düzenli bir artş ve azalışa ait bulgu bulunmamasına rağmen, Gedik (2008) tarafindan yapılan çalışmada Sosyal bilgiler ders kitaplarında yer almış olan güncel konuların miktarına bakıldığında,4. sınıftan 6. sınıfa kadar artıs göstererek devam ettiği görülmüştür.

Araştırma bulgularına göre, ders kitaplarında güncel konulara yer verilirken, en fazla gazete ve internet kaynaklarından yararlanılmıştır. Deveci (2007) tarafindan yapılan çalışma sonucunda sosyal bilgiler öğretmenlerinin derste güncel olayların kullanılmasının yararına inandıkları, güncel olayların öğretiminde en çok gazete ve televizyon gibi kaynakları kullandıkları bilgisine ulaşılmıştır. Bulgular, araştırma sonuçlarını destekler niteliktedir.

Akdağ ve diğerleri (2014) tarafindan yapılan çalışmada da öğretmenler, Sosyal Bilgiler ders kitaplarında güncel olayların yetersiz olduğu konusunda görüş bildirmişlerdir. Aynı şekilde Memişoğlu ve Güçin (2017) tarafindan yapılan çaıışmada da öğretmenler güncel konuları sosyal bilgiler dersinin tamamlayıcısı olarak gördüklerini, derste yeri geldikçe kullandıklarını ve ders kitaplarının güncel konular açısından yetersiz olduğunu ifade etmişlerdir. Araştırmada Sosyal Bilgiler ders kitapları incelendiğinde; 5. sınıflarda 1. kitapta bir ünitede ve 3. kitapta da 2 ünitede herhangi bir güncel konuya yer verilmezken 2. kitapta tüm ünitelerde güncel konulara yer verilmiştir. 6 . sınıflarda ise sadece 1 . kitapta 2 ünitede güncel konulara yer verilmezken diğer iki kitapta da tüm ünitelerde güncel konulara yer verildiği görülmüştür. 7. sınıflarda ise sadece 2. kitapta 1 ünitede güncel konulara yer verilmezken diğer kitaplarda güncel konulara yer verildiği tespit edilmiştir.

Tüm bu açıklamalar ışığında, düzenli bir güncel konu dağılımı olmamakla birlikte belirtilen kitaplardaki güncel konulara yer verilmeyen ünitelerde ne gibi güncel konulara yer verilebileceği konusunda öğretmen ve öğrenci görüşlerinin yer aldığı bir çalışma yapılabilir. Ders kitaplarında öğrenci ve öğretmenlerin özellikle yer verilmesini istedikleri güncel konuların neler olduğu araştrılarak, örnek ders kitabı veya etkinlik kitabı oluşturulabilir. Ayrıca hangi güncel konulara daha fazla ağılık verilmesi gerektiği konusunda akademisyenlerin görüşlerinin alındığı çalışmaların da yapııması faydalı olabilir. 


\section{Kaynakça}

Akdağ, H., Oğuz, R., Tatar, O. ve Subaşı, Y. (2014). Ortaokul sosyal bilgiler ders kitaplarının güncel olaylar bağlamında öğretmen görüşlerine göre değerlendirilmesi. Uluslararası Türk Eğitim Bilimleri Dergisi, 2(2), 49-65.

Akengin, H. ve İbrahimoğlu, Z. (2010). Sosyal Bilgiler dersinde karikatür kullanımının öğrencilerin akademik başarısına ve derse ilişkin görüşlerine etkisi. OMÜ Eğitim Fakültesi Dergisi, 29(2), 1-20.

Arın, D., Deveci, H. (2008). Sosyal bilgiler dersinde güncel olayların kullanımının öğrenci başarısına ve hatırda tutma düzeyine etkisi. Elektronik Sosyal Bilimler Dergisi, 7(26), 170-185.

Balcı, A. (2007). Sosyal Bilimlerde Araştırma, Yöntem, Teknik ve Illkeler. Ankara: Pegem Yayıncılık.

Bayır, Ö. G. (2010). Sosyal bilgiler dersinde güncel olaylardan yararlanmanın öğrencilerin eleştirel düşünme becerilerine etkisi, Yayınlanmamış Yüksek Lisans Tezi, Anadolu Üniversitesi, Eğitim Bilimleri Enstitüsü.

Binbaşıoğlu, C. (2004). Eğitimde Günlük Olaylar ve Eğitimi. Çağdaş Eğitim Dergisi, (315), 14-16.

Deveci, H. (2007). Sosyal Bilgiler dersinde güncel olayların öğretimine ilişkin öğretmen görüşleri. Kuram ve Uygulamada Eğitim Bilimleri Dergisi, 7(1), 417-451.

Deveci, H. ,Arın, D. (2008). Sosyal bilgiler dersinde güncel olayların kullanımının öğrenci başarısına ve hatırda tutma düzeyine etkisi. Elektronik Sosyal Bilimler Dergisi, 7(26), 170-185.

Dinç, A. , Acun, A. (2017). Sosyal bilgiler dersinde ekonomi ve sürdürülebilir kalkınma ile ilgili konuların öğretiminde güncel olayların kullanımına ilişkin öğretmen görüşleri. PAU Eğitim Fakültesi Dergisi (41), 29-46.

Erden, M. (Tarihsiz). Sosyal Bilgiler Öğretimi, Alkım Yayınları, Ankara.

Eryılmaz, Ö., Köse, T.Ç. (2017). Sosyal bilgiler dersinde güncel olay kullanımının öğrencilerin sosyal problemlere duyarlılılarına etkisi. Elektronik Sosyal Bilimler Dergisi, 16(62), 985-1000.

Evirgen, Ö.F. (2016). İlköğretim Sosyal Bilgiler Ders Kitabı 7, Ekoyay Yayıncılık, Ankara.

Gedik, H. D. (2008). Sosyal bilgiler ders kitaplarında güncel konular. Türkiye Sosyal Araştrrmalar Dergisi, 12 (1), $117-134$.

Gedik, H. D. (2010). Güncel olayların ilköğretim sosyal bilgiler derslerinde kullanımı ve öğrenci görüşleri. Ahi Evran Üniversitesi Eğitim Fakültesi Dergisi, 11(2), 97-118.

Kabapınar, F. (2003). Kavram yanılgılarının ölçülmesinde kullanılabilecek bir ölçeğin bilgi kavrama düzeyini ölçmeyi amaçlayan ölçekten farklılıkları. Kuram ve Uygulamada Eğitim Yönetimi, 230, 40-47.

Karabıyık, E. Ü. (2014). İlköğretim Sosyal Bilgiler Ders Kitabı 7, Evren Yayıncılık, Ankara

Karabıyık, E.Ü. (2014). ilköğretim Sosyal Bilgiler Ders Kitabı 6, Evren Yayıncılık, Ankara.

Karabıyık, E.Ü. (2015). illköğretim Sosyal Bilgiler Ders Kitabı 5, Evren Yayıncılık, Ankara.

Kaltsounis, T. (1987). Teaching Social Studies In The Elementary School: The Basics For Citizenship. (2nd ed.) New Jersey: Prentice Hall. Kornblum, W. \& Julian, J. (1991). Social problems. (Seventh Edition). New Jersey: Prantice Hall.

Komisyon (2015). İlköğretim Sosyal Bilgiler Ders Kitabı 6, MEB Yayınları, Ankara.

Komisyon (2016). illköğretim Sosyal Bilgiler Ders Kitabı 7, Korza Yayıncılık, Ankara.

Memişoğlu, H., Güçin, G. (2017). Sosyal bilgiler öğretmenlerinin görüşlerine göre güncel konuların öğretimi. International Journal Of Social Sciences and Education Research, 3(4), 1274-1295.

Michealis, J. U. \& Garcia, J. (1996). Social Studies For Children: A Guide To Basic Instruction. (11th ed.). Boston: Allyn and Bacon. Oaks, London: Sage Publications.

Miles, M. B. \& Huberman,A. M. (1994). Qualitative Data Analysis (2nd ed.). Thousand Oaks, London: Sage Publications.

Nas, R. (2000). Hayat Bilgisi ve Sosyal Bilgiler Öğretimi, Ezgi Kitabevi Yayınları, Bursa.

Özensoy, A. U. ,Aynacı, C. (2016). İlköğretim Sosyal Bilgiler Ders Kitabı 5, Berkay Yayıncılık, Ankara.

Özensoy, A.U. (2014). İlköğretim Sosyal Bilgiler Ders Kitabı 5, Harf Yayıncılık, Ankara.

Smith, D. O. (1963). Current Events in The Intermediate Grades of a Modern Elementary School, (MS Thesis, Kean University). New Jersey.

Şimşek, N. (2017). Güncel Olaylarla Sosyal Bilgiler Öğretimi. Ramazan Sever, Mesut Aydın, Erol Koçoğlu (Ed.), Alternatif Yaklaşımlarla Sosyal Bilgiler Eğitimi. Pegem Yayınları, Ankara.

Tavşancıl, E. ve Aslan, E. (2001). Sözel, Yazılı ve Diğer Materyaller için İçerik Analizi ve Uygulama Örnekleri. Epsilon Yayınevi, İstanbul. Tekten, Z. (2015). Illköğretim Sosyal Bilgiler Ders Kitabı 6, Yakınçağ Yayınları, Ankara.

Ünlüer, G. (2008). Sosyal bilgiler dersinde gazete kullanımının öğrencilerin akademik başarılarına ve tutumlarına etkisi. Yayınlanmamış Doktora Tezi, Anadolu Üniversitesi, Eğitim Bilimleri Enstitüsü.

Wilson, L. (2002). Reading to Live. Heineman, Partsmouth, NH USA.

Yıldırım, A. ve Şimşek H. (2013). Sosyal Bilimlerde Nitel Araştırma Yöntemleri. Seçkin Yayıncılık, Ankara. 